\title{
ІДЕЯ ІСТОРИЧНОГО ФІНАЛІЗМУ У СВІТОВІЙ ФІЛОСОФСЬКІЙ ДУМЦІ
}

\begin{abstract}
О.П. Панафідіна
Цілісна концепція телеологічно-фіналістського бачення світової історії вперше була сформульована в межах теології історії, хоча її витоки необхідно шукати в міфологічній свідомості, зокрема в т. зв. есхатологічних міфах. Останні можна вважати відносно пізнім надбанням людства, адже міф у класичному розумінні цього слова є, по суті, позаісторичним явищем. Завдяки такому його атрибуту як синкретизм формується специфічний «міфологічний час», в якому, за А.Ф.Лосєвим, «кожна мить невідокремлена від вічності», адже те, що дається нам «у вигляді переходу від однієї речі до іншої, насправді є не стільки таким переходом речей і явищ, скільки взаємним і нерухомим зчіплюванням» $[20$, с. 36$]$. Відомо, що в первісну епоху існувало табу на вияв особистісної ініціативи, натомість за норму визнавали колективну підтримку раз і назавжди встановленого порядку в організації суспільного жкиття. А тому щоденні ритуали були покликані забезпечувати «вічне повернення» природних та життєвих циклів. За такої умови майбутне взагалі не має будь-якої цінності для носія міфологічної свідомості, що характеризуеться виключно ретроспективною орієнтацією.

Однак культурні зміни, які одночасно е і причиною й наслідком зміни самої людини, з часом почали трактуватися як деградація Космосу, що супроводжувалося страхом перед невідомим майбутнім, котре вже втрачало ознаки очевидності. Відтак першою реакцією людини на значні культурні зміни (i як їх результат - розклад первіснообщинного суспільства) стала поява есхатологічних міфів, що лежать і в основі таких релігій як іудаӥзм та християнство (мова йде про міфологічні
\end{abstract}


ідеї стосовно кіншя світу у священній для представників обох релігій книзі - Старому Заповіті). Якщо основною темою архаїчних міфів виступае ідея тривалого творення Космосу із Хаосу, то більш пізні міфи оповідають про світову катастрофу, як правило, у вигляді «світової пожежі» або ж «світового потопу». Ії причиною визнається моральна деградація людей внаслідок руйнації традиційних устоїв, вироблених «великими попередниками». Причому даний мотив присутній і в багатьох філософських концепціях, наприклад, Платона, частково Августина, Віко, Гегеля, Маркса та ін.

В епоху середньовіччя під впливом християнської релігії починає трансформуватись уявлення про час i, відповідно, про історичний процес (хоча підгрунтя такого уявлення було закладене ще в іудейській традиціi). Міфологема «золотого віку», орієнтована виключно на минулий час, для носіїв релігійної свідомості замінюеться орієнтацією на майбутне. Відсутність прямих аналогій між тим, що відбувається, і тим, шо вже мало місце, викликало намагання людини «схопити» плинність часу (як причини змін) за допомогою винесення «справжнього буття» за межі реального світу. Час відокремлюеться від вічності, а остання, у свою чергу, обумовлюе спрямованість першого. Таким чином, історичний час «розтягується» у лінію; він має початок та кінець, який одночасно виступає й метою історії.

Саме 3 такої світоглядної позиції була сформульована теолого-теоретична концепція Аврелія Августина, яку можна вважати першою спробою цілісного осмислення світової історії, історії всього людства, з точки зору їі мети та сенсу. Вона у концентрованому вигляді викладена в роботі «Civitas Dei» («Про Грал Божий»), якій Августин присвятив близько двадцяти останніх років свого життя.

В історіософській концепції Блаженного Августина історичний процес постае як «стріла часу, що летить» від минулого (гріхопадіння Адама) через теперішне (час існування двох градів у земному світі, який поділений на шість періодів, що символізує, напевне, дні творення Богом світу) у майбутне (відокремлення земного граду від граду Божого через Страшний суд). Ця схема демонструє лінійність історії, оскільки «здоровий глузд розриває ... вимишлені уявою кола, що обертаються» $[1$, с.595]; натомість «жертва Христа», як знакова подія людської історії, розмикає їі, роблячи кожен момент людського життя на землі унікальним, а час незворотнім. Відтак історія, яка оголошуеться детермінованою проявом Божої волі, має свій початок і свій кінець. Причому їі кінець (лат. finis) одночасно виступає й метою історичного процесу, який не розвивається, а твориться у вигляді «ві- 
чного міста», що не підлягає розрусі й загибелі. Воно, за Августином, має постати в результаті «необхідного кінця обох градів - земного і небесного» після «останнього Божого суду» над «живими і мертвими». Тільки тоді, в кінці земної історіі, «справжне і повне щастя перетвориться на долю добрих, а заслужене і величезне нещастя - на долю злих» [1, с. 1061]. Саме в цьому напрямку рухається історія-у напрямку людського спасіння, причому спасіння індивідуального.

Необхідно відмітити, що концепція Августина не грунтується виключно на релігійній традиції. Важливим і1і джерелом можна також вважати античну філософію, зокрема вчення Платона, Плотіна, Цицерона та ін. Так, А.А. Чанишев зазначае, що Августин відтворюе в рамках християнської світоглядної схеми такий елемент античної традиції, як розрізнення між «(земним) царством» та «державою» з усіма витікаючими 3 цього наслідками. Поняття, аналогічне «державі» давньогрецьких авторів, він передае терміном «сіvitas», під яким розуміе таке політичне співтовариство, в котрому має місце справедливе правління. Його можна порівняти з ідеальною державою Платона як ідеєю досконалої політичної організації. Причому обидва мислителя пояснюють причину відсутності справедливого правління в сучасних їм суспільствах законом деградації (у Платона - на основі філософськоміфологічного світогляду, в Августина - релігійного, тобто внаслідок гріхопадіння). По стосуеться поняття «царство», то воно використовується в єпископа Гіппонійського на позначення реального історичного державного утворення, подібного язичницькому Ассирійському царству, або ж Риму [32, с. 130] (аналог у Платона-конкретно-чуттеве втілення ідеї держави, що не відповідає досконалості взірця).

Отже, августинівський Civitas Dei - це одночасно і взірець справедливої держави, і вічний досконалий світ, в якому перебувають безсмертні, і результат боротьби між земним градом та Градом Божим у земному світі, і кінцева мета історичного процесу, провіденційно визначена Божою волею. Історія, яка, серед іншого, зараховуеться Августином до творінь Божих, реалізується в земному світі як арені співіснування двох градів, приречених на загибель. Завершення історії ознаменує собою реалізацію найвищого блага, яким, 3 точки зору граду Божого, виступае вічне життя. Відтак кінець граду Божого, що тимчасово «перебуває в земних мандрах» і «має небесний світ у вірі й за цією вірою живе праведно», та земного граду, який перебуває у гріховності і в земному світі не долучився до праведного життя, стане початком нового життя, де не буде несправедливості, нещасть, нерівності тощо.

«Всесвітнє вічне місто» відтепер стає невід'ємним елементом світо- 
гляду численних мислителів, які згодом розробляли соціально-філософські концепції. Що стосуеться епохи середньовіччя, то авторитет Августина (як одного з отців церкви) визнавався беззаперечним. Протягом майже десяти століть церковно-християнське вчення було мірилом істинного та хибного, правильного й неправильного. Проте після завершення епохи середньовіччя починає домінувати світська система цінностей. Як стверджуе Р. Гвардіні, в епоху Відродження зароджується нова, ворожа християнському Одкровенню чи, принаймні, байдужа до нього орієнтапія, яка 3 того часу визначала подальший розвиток культури [9, с. 261]. Тому в цей час внаслідок секуляризації свідомості розуміння кінця історії у вигляді ідеї «небесного царства», яка в середні віки практично не зазнавала кардинальних трансформацій, поступово перетворюеться на ідею земного раю.

Секуляризація релігійної теми Раю як Небесного Єрусалиму призвела до появи ідеалізованого образу суспільства. 3'являються численні утопії, об'єднані схожою схемою оповіді: головним героєм виступає мандрівник, який відвідуе деяку невідому країну, де спостерігае досконалу, з точки зору автора, суспільну організацію. Так побудовані «Утопія» Т. Мора, «Місто сонця» Т. Кампанелли, «Христианополіс» I. Андрее, «Нова Атлантида» Ф.Бекона та інші подібні «урбаністичні фантазіі» XVI-XVII століть. Звичайно, прообразом багатьох 3 них виступає концепція ідеальної держави Платона, однак ідея розумно та гармонійно облаштованого соціального простору в епоху пізнього Відродження була своєрідно поєднана зі своїм новозавітним прототипом [3, с. 104]. Тому цілком доречно, на наш погляд, припустити, що утопічні уявлення про досконалу соціальну організацію пов'язані 3 можливою кінцевою точкою історії. Спочатку, під впливом ейфорії від численних географічних відкриттів, виникла ідея, згідно з якою ідеальне місто-держава існуе вже зараз, десь на невідомому острові, на цій землі, а не в потойбічному житті, після смерті. Проте, чим більше відкриттів робили мореплавці, тим менше залишалося надій на те, що таке місце реально буде знайдене. Відтак «просторові» утопї поступаються місцем «часовим» (ухроніям) з їх орієнтацією на майбутній час $[15$, с. 47], які чудово вписуються в християнську лінійну схему осмислення історичного процесу. Так, наприклад, вже в утопіях Я. Комеліуса та Г.Лейбніца межі ідеального конкретного християнського міста-держави знову розширюються до загальнолюдських розмірів [3, с. 104]. Причому зустріч європейців 3 кардинально відмінними способами організації людської життедіяльності, яка, здавалось, мала б підірвати їх віру в єдність загальнолюдської історії, насправді стала 
причиною своерідної «мутації ідеї прогресу. Факт розмаїття варіантів культурного розвитку в різних регіонах світу було проінтерпретовано як перебування народів на якісно відмінних стадіях загальнолюдської «драбини прогресу». Тобто вихід західних інтелектуалів при осмисленні всесвітньо-історичного проџесу за межі європейського регіону на практиці супроводжувався формуванням такого світоглядного принципу, як європоцентризм (виникае і концептуально оформлюеться дихотомія «примітивність - цивілізація»).

В епоху Просвітництва раціоналізм картезіанського гатунку, що передбачав рух думки від розуму до природи, замінюється «натуралістичним» раціоналізмом, який в своїй основі мав протилежну орієнтацію- - рух від природи до розуму. Подібна трансформація парадигми мислення грунтувалася на тій ідеї, що саме природа породжує розумних людей, а вони, у свою чергу, мають наслідувати $\dddot{1} 1$ «природній порядок» [26, с. 113]. Відтак пріоритетним мае бути дослідження самої природи, яка $\epsilon$ не просто об'єктом пізнання, а й джерелом та середовищем існування людини, місцем реалізації її історії. Не дивно, що в цей час осмислення історнчного процесу відбуваеться 3 позиції т. зв. «натуралістичного історизму», який можна вважати першою спробою зберегти віру в смисл історії, у ї̈ щасливий кінець, але без Божественного втручання. Отже, починаючи з XVIII століття «мислена фігура» (Клеменс Фрідріх) кінця історії набуває нового звучання за рахунок ідеї прогресивної спрямованості суспільного розвитку. Відтепер історія не твориться якоюсь зовнішньою силою, як це було в концепції Августина, а саме розвивається завдяки здатності людини до розумної діяльності, спрямованої на забезпечення $\dddot{11 ~ к о м ф о р т н о г о ~ і с н у в а н н я ~}$ в межах природного та створеного нею культурного простору. Сама ж людина розглядається, за влучним виразом Т. Гоббса, як «обдарована розумом тварина». Просвітниками проголошується ідея існування вічної природи людини, пізнавши яку можна з великою мірою достовірності спрогнозувати модель найоптимальнішого суспільного облаштування. Показово, що під «Природою людини» розуміли в той час «суму їі природних здібностей та сил, таких, як здібність харчуватися, рухатися, розмножуватися, таких, як почуття, розум тощо» $[12$, c. 510-511].

В пілому просвітники, осмислюючи всесвітній історичний процес, оптимістично дивилися у майбутне. Майже у всіх із них історичний прогрес ототожнювався з прогресом людського розуму. Останній у своєму розвитку проходив декілька етапів, які співпадають 3 конкретними історичними епохами. А оскільки історичний процес органічно вклю- 
чений у природній, то закони природи одночасно виступають й законами історії. Отже, згідно з Вольтером, ІІ.Л. Монтеск'є, А.Р. Тюрго, Ж.А. Кондорсе та ін. мислителями французького Просвітництва, суспільство постійно рухається від «нерозумного» стану до «розумного», у напрямку встановлення на землі Царства Розуму, де кожна людина стане щасливою.

Як слушно зауважує T.I. Ящук, у XVIII столітті европейська культура відкрила для себе світ історії, який досі ховався в тіні античного космосу, або біблійної священної історії. Осмислення досвіду минулого у формі «філософської історії» зробило можливим пояснення подій всесвітньої історії як певного цілого [34, с. 115]. I хоча питання про кінець історії не ставилося просвітниками у явній формі, однак, на наш погляд, висловлена ними ідея досягнення щасливого майбутнього (завдяки здатності людського розуму до цілеспрямованої діяльності) стала основою його розробки тими мислителями, які, спираючись на здобутки своїх попередників, в подальшому спробували сформулювати шляхи досягнення справедливого суспільного устрою (тобто більше уваги приділили не аналізу минулого, а конструюванню майбутнього). Таким чином, лінійна модель пояснення історії, що іманентно містить у собі ідею фіналу історичного процесу, знову стає домінуючою в європейській філософській думці. Однак тепер вона набула секуляризованого змісту і саме людина визнається творцем власного майбутнього.

Однією із перших спроб підведення підсумку теоретичних пошуків історизму Просвітництва та здійснення критичної рефлексії стосовно більшості його тез можна вважати філософсько-історичну концепцію І.Г. Гердера. Він у праці «Ідеї до філософії історії людства» визначив мету історичного процесу як створення раціоналізованого гуманістичного суспільства, яке сприятиме досягненню загальнолюдського щастя. На його думку, «сутність людства, мета і доля людського роду» базуються на «справедливості та розсудливості», а всесвітня історія характеризується як «поступальний рух добра», тобто як прогрес гуманності $[11$, с. 456]. Причому процес оволодіння духом гуманності не $\varepsilon$ безкінечним. Рано чи пізно людський рід досягне найвищого рівня моральної досконалості («богоподібної гуманності»), що на зміну людині як вершині Божого творіння прийдуть істоти вищого роду. Відтак історія виступае у Гердера лише як засіб досягнення прийдешнього світу досконалості, а отже набуває яскраво вираженого фіналістського характеру [26, с. 180].

Дещо окремо від новочасного європейського філософсько-історичного дискурсу стоїть концепція «Вічної Ідеальної Історії» італійсько- 
го мислителя Дж. Віко, що виступае як своерідний синтез античної циклічної моделі історії та релігійного провіденціалізму. Відповідно до цієї «нової науки», «протікають у часі Історії усіх Націй у їх виникненні, русі вперед, функціонуванні, занепаді та кінці» [8, с. 118]. Необхідно зазначити, що філософсько-історичні ідеї Віко займають проміжне становище між середньовічною та новочасною картинами світу, що відобразилося, зокрема, й у назві запропонованої ним нової науки про загальну природу націй - «Раціональна Громадянська Теологія Божественного Провидіння».

Концепція Віко по праву може вважатися однією з перших спроб узагальнення історичного розвитку народів (в т. ч. й неєвропейських) i виокремлення в ньому таких епох, що послідовно змінюють одна одну й мають значимість самі по собі, а не як основа для подальшого розвитку людства. Так, італійський мислитель зауважує, що усі народи незалежно один від одного проходять три основні періоди свого існування: Вік Богів (коли люди-язичники гадали, що живуть під божественним управлінням), Вік Героїв (коли в Аристократичних Республіках управляли герої на основі ідеї переважання своєї природи над природою плебеїв) та Вік Людей (коли всі люди визнали, що вони є рівними за своєю природою). Така хода історії намічена провидінням від самого початку зародження «Націй». Свідченням цього він називає наявність у різних стародавніх народів, що безпосередньо не контактували між собою, схожих уявлень про богів та героїв, а також поява у них релігійних вірувань, шлюбу та поховання померлих як засадничих елементів культури. Дж. Мердок відносить останні до т. зв. універсалій культури, тобто до елементів загальнолюдської культури, котрі проявляються в різних «модифікаціях» у різних народів.

Віко у роботі «Засади нової науки про загальну природу націй. . . часто посилається на «божественного Платона», ставлячи останньому в заслугу висловлену ним ідею щодо ролі Провидіння в житті людей. Крім того, тезу Віко про «вічне повернення людських речей» також можна порівняти 3 тезою античного мислителя про необхідний кругообіг форм правління. Причому обидва філософи проголошували причиною постійного суспільного коловороту недосконалу природу людини. Однак, якщо у Платона діє закон суспільної деградації, що можна розцінювати як відголосок міфологічного типу свідомості, то у Віко цикл відбувається по висхідній лінії (що демонструе вплив на нього Просвітництва). В будь-якому разі в обох концепціях присутній елемент «ідеальної держави» як межа людських можливостей, що дає підстави розглядати і Платона, і Віко як мислителів, які так чи інакше 
причетні до розробки ідеї кінця історії.

Цікаво прослідкувати й вплив християнської традиції на формування основних положень філософії історії Віко. Так, останній постійно акцентуе увагу на ролі релігії для кожної історичної епохи, і тим самим доходить висновку, що «якщо народи втратять релігію, то в них не залишиться нічого, що примушувало б їх жити в суспільстві» $[8$, c. 471-472]. Крім того, з огляду на це необхідно відмітити, що основні філософсько-історичні тези Віко в загальних рисах в подальшому стануть основою для концепції Гегеля (не зважаючи на різні моделі пояснення історичного процесу): вся історія у «згорнутому вигляді» міститься у Божому Провидінні; зміна історичних епох наперед визначена; людина рано чи пізно вийде на магістральний шлях розвитку історії; ідеальний тип держави є універсальним тощо [26, с. 163-164].

Особливу роль ідея завершення історії відіграє у тих філософів, які намагалися побудувати класичні світоглядні системи. Причому філософсько-історична проблематика могла виступати у них як другорядна, але необхідна для цілісного вираження свого світобачення. Яскравим прикладом тут може слугувати вчення I. Канта, який здебільшого концентрував свою увагу на гносеологічних та етичних питаннях, однак у 1784 році написав статтю «Ідея всезагальної історії у всесвітньо-громадському плані» з метою прояснити в.ласну позицію 3 питань філософії історії. Необхідно зазначити, що, на думку деяких сучасних дослідників, кантівський ідеал всесвітньої республіки перебуває за межами дискурсу «кінця історії» (див., наприклад, [19, с. 32]). Однак, 3 нашої точки зору, висловлені ним ідеї з приводу необхідності створення «фі.лософської історії, яка обов'язково має включати в себе обгрунтування суспільного ідеалу, сприяли в подальшому розробці в т. ч. й проблематики кінця історії.

У названій праці Кант показав, як має бути охарактеризована всесвітня історія з точки зору трансцендентального ідеалізму. Так, відповідно до його концепціі, історія має здатність самостійно розвиватися (а не творитися деякою надприродною силою). Кінцеву мету історичного процесу, за Кантом, «намічає» природа, яка має по відношенню до людей певний «таємний план», але реалізуе його саме людина, точніше, людство, оскільки «обдарована розумом тварина» стає дійсно людиною, тобто моральною і культурною істотою, лише в ході тривалого процесу культурогенезу - завдяки акумуляції і передачі власного досвіду від покоління до покоління. Відтак, історія, з огляду на ідеї Канта, спрямовується на свідому реалізацію людьми, наділеними необмеженою свободою, категоричного імперативу (як апріорного 
принципу «чистої моральної свідомості») за допомогою встановлення «внутрішньо і для цієі мети також зовнішньо досконалого державного устрою як єдиного стану, в якому вона [тобто історія людського роду] може повністю розвинути усі задатки, вкладені нею в людство» $[16$, c. 18-19]. Отже, від людини як складової людського роду залежить настання «радісного для наших нащадків моменту», тобто справедливого «всезагального правового громадянського суспільства».

Отже, в філософській системі Канта сформульована мета історичного процесу як ідеальний, на думку їі автора, суспільний устрій. Однак, якщо у цього німецького мислителя досягнення подібної мети виступає як «величезна проблема для людського роду», котру «повністю вирішити неможливо», а можна лише безкінечно наближатися до цієї ідеї, то у іншого німецького класика - Г.В.Ф. Гегеля - «кінець історії» перетворився з суспільного ідеалу на суспільну реальність, свідком якої, на його думку, був він сам. Це стало можливим тому, що Гегель «онтологізував» належне, зробивши його об'єктивно-належним. Так, відповідно до його концепції, історичний процес не містить у собі поді.лу на «суще» та «належне», оскільки «належне» від самого початку виступає як «суще». Тому «філософська історія» (тобто вчення самого Гегеля), на відміну від «початкової» та «рефлективної» історій, спроможна побачити за випадковою наявною формою необхідний зв'язок, пізнати сенс історії $[17$, с. 60-75]. Трансцендентне у нього перестає бути непізнаваним.

Аналіз філософсько-історичних поглядів Гегеля, детально викладених у його «Лекціях. . . », дає підстави стверджувати, що він повністю прийняв та відтворив основну схему іудео-християнської трактовки історичного процесу, включаючи ідею його фіналу. Однак, тезу про кінець історії німецький філософ намагався обгрунтувати за допомогою раціоналістичних засобів, а не сприймав їі на віру. Для реалізації такого завдання він використовував основні положення власної філософської системи об'єктивного ідеалізму. Відомо, що субстанційною основою буття, за Гегелем, виступає чисте мислення (об'єктивна ідея), яке наділене поняттями (категоріями), що за законами діалектики переходять одне в одне. Це $є$ логічний, а не часовий процес. Тому, коли усі можливі варіанти чистих перетворень вичерпуються, об'єктивна ідея здійснює вільний акт онтологічного самовідчуження, результатом чого стає поява предметного світу. Останній виступає у вченні Гегеля інобуттям чистого мислення, його протилежністю і одночасно засобом самопізнання об'єктивної ідеї, яке розгортається в історії. Отже, історичний процес-це «шлях визволення духовної субстанції», «процес 
розкриття у дійсності своєї в-собі-і-для-себе-сущої сутності», в результаті якого вона стає «світовим духом» (або ж абсолютним духом).

Історія у Гегеля, як і в християнських філософів, має початок та кінець. Вона починається з появою держави, котра уособлюе собою «народний дух» («Volksgeist») як фрагмент майбутньої світової історії, як конкретний прояв «Світового Духу» («Weltgeist»). Отже, «народний дух» розглядається Гегелем як партикулярний дух, що може 3 часом зникнути, виконавши свое призначення. Але світовий дух ніколи не зникне, він є вічним. («Тривалість часу є дещо цілком відносне, а дух вічний. Тривалість у власному сенсі для нього не існує» [10, с. 152].) На історичній арені він проявляється, коли різні держави вступають у міжнародні взаємини, керуючись, як їм здається, виключно власними інтересами. Проте насправді вони реалізують мету світового розуму, яка одночасно виступае іманентною метою всесвітньої історії. Категорія світового розуму використовуеться німецьким мислителем як деяка абстракція, на позначення духу у відриві від людини. Тут, на наш погляд, яскраво проявляеться телеологічність в осмисленні історичного процесу. Людина є представником абсолютного духу, «інструментом» його поступального розвитку і водночас «самоціллю», тобто світовий розум визначає для людей мету їх діяльності, хоча й визнається, що їі реалізація співпадає з інтересами самих людей. Даний феномен Гегель кваліфікував як «хитрість розуму». Останній, самопізнаючи себе в історії і реалізуючи свою свободу руками людей, здійснюе себе у світі і тим самим визначае мету всесвітньої історії. Причому все, що існувало колись й існуе зараз, набувае деякого сенсу тільки у співвіднесенні з цією метою. Тобто рух історії пояснюється Гегелем не $з$ позиції минулого, а $з$ точки зору майбутнього. Адже саме цього вимагае його філософська система, яка обов'язково мае бути завершеною. Всесвітня історія як цілісний процес завершуеться у нього всередині самої історії, коли дух повернеться зі стану інобуття в себе, але вже знаючи, що він $\epsilon$, тобто «розгорнувши» себе.

Оскільки світова історія має «розумний план», то усі їі етапи розглядаються в концепції Гегеля з огляду на їі кінцеву мету. Крім того, сам механізм переходу від однієї історичної сходинки до іншої теж просякнутий телеологічністю: дух народу гине й народ сходить з історичної арени тому, що він уже реалізував своє призначення, власну історичну мету і не спроможний здійснити більш високу мету, призначену для інших [24, с. 31-32]. Так, за Гегелем, «всесвітня історія направляється зі Сходу на Захід, адже Європа є безумовно кінець всесвітньої історії, а Азія її початок» [10, с. 147]. Він порівнюе конкретні 
історичні періоди з віком людини і демонструе процес «розвитку поняття свободи», що протікає у всесвітній історії. Схід-дитячий вік історії-знає тільки, що одна людина вільна, а всі інші ій підкорюються. Грецький світ, в якому «формуються індивідуальності», співпадае 3 юнацьким віком, на зміну якому приходить вік змужнілості історіїримська держава, де зникає індивідуум, який, однак, досягає власних цілей у загальній меті. Тому грецький та римський світ знають, що деякі вільні. I тільки германські народи, які живуть у старечому віці історії, завдяки християнству дійшли до усвідомлення, що вільним $\epsilon$ кожний $[10$, с. $147-152]$. Відтак тільки в кінці історії субстанційна свобода стае суб'єктивною. Для світового духу це означае завершення діалектичних перетворень в результаті своєї повної реалізапііі. В цьому проявляється відоме протиріччя між гегелівською системою та його методом.

Окремо необхідно відмітити, що з огляду на досліджувану проблематику (постановка питання про кінець історії у світовій філософській думці) філософсько-історична концепція Гегеля може розглядатися як основа для подальшої її (проблематики) розробки в найрізноманітніших варіагіях. Це можна, на наш погляд, пояснити тим, що німецький мислитель намагався при осмисленні історичного процесу поєднати роль трансцендентного та іманентного, поглянути на нього як на цілісність, що, безумовно, має сенс та спрямованість свого розвитку, і одночасно реалізується в ході людської діяльності. Тобто у вченні Гегеля зосереджені усі можливі варіанти філософського пояснення суті історії. Можна не погоджуватися з окремими елементами його філософсько-історичної концепції, але не можна відкинути її в цілому, адже вона увібрала в себе усі попередні досягнення в даній царині людського духу.

Ti дослідники, які орієнтувалися на ідеал «науковості», звичайно, відмовлялися від ідеї існування в історії деякої субстанції. Цим шляхом пішли позитивісти та марксисти. Так, засновник позитивізму та «соціальної фізики» О. Конт намагався здійснити докорінне реформування філософії, проголосивши необхідність відмови від вивчення нею «сутностей, що осягаються розумом». На його переконання, на зміну «спекулятивній метафізиці» має прийти «позитивна філософія», яка має займатися вивченням «загальних ідей різних наук», що разом утворюють єдину систему і послуговуються одним методом дослідження. На практиці це означало, що методологія природничих наук визнавалась цілком придатною для вивчення суспільних явищ. Здавалося б, що 3 телеологічним та фіналістським підходом до пояснення історично- 
го процесу покінчено назавжди, однак «позитивна теорія суспільного прогресу» Конта демонструе зворотне.

Розробляючи теорію соціальної статики та соціальної динаміки, він спираеться на ідеї своїх попередників - деяких французьких просвітників. Так, зокрема, Конт поеднуе проблематику Монтеск'є щодо детермінізму історичних і суспільних явищ 3 проблематикою Кондорсе, пов'язаною $з$ неминучістю поступу розуму людини в умовах невідворотного порядку. На цій основі він проголошуе, що суспільні явища підпорядковані суворому детермінізму, який набуває форми неминучої зміни суспільства під натиском розуму людини [2, с. 99]. Відтак розум людини вказуе напрям історії, а остання потрібна тільки для того, аби він реалізував свое покликання - контроль за егоїстичними інтересами людей. Причому поступальний рух суспільства від «теологічної» стадії до «метафізичної», а від неї до «позитивної» характеризується Контом як «логічно необхідний» процес. Тому історія знову набуває телеологічного та фіналістського характеру, адже вона спрямовується до вищої і кінцевої стадії свого розвитку - «позитивної». Саме на цій стадії реалізуеться в межах всього людства ідеальне суспільство, організоване за такою формулою: любов як принцип, порядок як основа, прогрес як мета.

3 даного приводу цікаву думку висловив Р. Арон: «Тй, кого вважають засновником позитивної науки, може також подаватись як останній прихильник християнського провіденціалізму» [2, с. 100]. Дійсно, Конт, прагнучи звести нескінченну різноманітність суспільств у просторі й часі до «основного ряду» становлення людського роду, до «единого задуму» та до остаточного стану розуму людини на основі виявлення загальних історичних законів, легко перейшов від наукової концепції пояснення історичного процесу до нової версії провидіння. Новизна полягае лише в тому, що історія спрямовуеться незмінною природою людини, яка, у свою чергу, підпорядковується невідворотним законам. Пізнавши ці закони, розум зможе приборкати егоїстичні, ірраціональні людські потяги, і тим самим сприятиме завершенню історії встановленням безконфліктного альтруїстичного «соціального організму» в межах всього людства.

Подібні світоглядні метаморфози можна спостерігати на прикладі вчення ще одного 3 класиків позитивізму - англійського дослідника Г. Спенсера. Його уявлення про соціальну еволюцію (над-органічну фазу «великої еволюції») як про поеднання прогресу та регресу, як про таку, що неминуче переходить у стадію диссолюції, можна було б кваліфікувати як вихід за межі класичного дискурсу про досягнення 
суспільством свого кінщевого досконалого стану. Проте, як і у випадку 3 Контом, такі висновки були б досить поспішними.

Спенсер, говорячи про еволюцію суспільства, висловлюе тезу, відповідно до якої визнається можливість досягнення «повної рівноваги» у взаєминах між людьми за допомогою «поступового наближення до гармонії між духовною природою людини та умовами її існування». Причому усі зміни в світі людини, в т.ч. і $\dddot{1}$ моральне удосконалення, «запрограмовані» еволюцією, що розвиваеться за власними універсальними законами. Людині залишається тільки здійснювати на свідомому та підсвідомому рівнях пошук найефективніших засобів пристосування до оточуючого середовища. Отже, в концепції Спенсера, не зважаючи на проголошений суто науковий підхід, зберігається характерна для усієї попередньої філософії ідея існування надлюдської сили, що зумовлюе спрямованість історичного процесу. Замість Бога, провидіння, Світового розуму, незмінної природи людини і т. ін. англійським філософом подібною силою проголошується еволюція. Зрештою, Спенсер із безпристрасного спостерігача перетворюється на оракула майбутнього, де «силами еволюції» сформується справедливе суспільство, в якому кожна людина зможе досягти «кінцевої мети свого існування» - щастя [26, с. 276-277].

До розробників ідеї завершення історії мокна, як нам здаеться, зарахувати й таких мислителів, як К. Маркс та Ф.Енгельс. У їх численних роботах марно шукати прямих свідчень на підтвердження цієї тези. Більше того, вони категорично заперечували, що «історія ... може отримати остаточне завершення в деякому досконалому, ідеальному стані людства», акцентуючи увагу на «безкінечному розвитку людського суспільства від нижчого щабля до вищого» [33, с. 375-376]. Дійсно, матеріалістичне розуміння історії базується на таких основних принципах, як визнання закономірності суспільного розвитку, існування причинно-наслідкових зв'язків і залежностей (детермінізму), поступального і прогресивного розвитку суспільства, який має певні особливості у порівнянні з природними процесами. Отже, Маркс та Енгельс намагалися науково пояснити хід історії (як і позитивісти), і це, на думку багатьох дослідників, наприклад, Р. Бауермана, нібито дає достатні підстави стверджувати, що для їх вчення не була прнтаманна телеологічна ідея існування «кінцевої мети» історії [4, с. 49-50].

Проте саме основоположникам марксизму належить теорія «наукового комунізму», в якій капіталістична суспільно-економічна формація характеризуеться як кінець «передісторії» людства, а комуністична - як початок «справжньої історії», коли реалізуеться «реальний 
гуманізм і вільний розвиток кожного стане умовою вільного розвитку усіх». Відтак комуністичний проект можна вважати показником глибокої суспільної кризи й певним футурологічним прогнозом, версією історичного шляху, відмінною від версій «кінця історії, притаманних есхатології [19, с. 38]. Так, зокрема, у «Зауваженнях до програми німецької робітничої партії» («Критиці Готської програми» [21]) Маркс в загальних рисах (мабуть, свідомо, аби не бути звинуваченим в утопізмі, тобто прив'язаності до окресленого ідеалу) змалював майбутне комуністичне суспільство і поставив питання про дві його фази, про соціалістичну революцію як засіб переходу до нової формації тощо. На його думку, і на цьому неодноразово було наголошено, перехід від «царства необхідності» до «царства свободи» $е$ історичною закономірністю і не залежить від бажання людей, адже в основі історичної динаміки лежить рівень розвитку продуктивних сил суспільства.

Проте, як зауважуе А.Валіцький, спираючись на Г.Лукача та Ж. Кальве, Марксова інтелектуальна спадщина характеризується «парадоксальним дуалізмом». 3 одного боку, історичний матеріалізм трактуе історію як творену людьми, але не контрольовану й не плановану ними. Тобто це е теорія творення історії в структурі самозбагачувального відчуження (відчуження виробника від продуктів його діяльності, відчуження виробника від власної активності та відчуження людини від родової сутності, а історичного процесу від гуманістичної спрямованості), що дійсно претендує на статус науковості. А $з$ іншого боку, теорія «наукового комунізму» (включно з теорією соціалізму як нижчої фази) вимагала кардинально іншого - свідомого творення історії, спираючись на раціональні знання, вільну реалізацію цілей, визначених нашою невідчуженою родовою сутністю. На цій підставі польський дослідник робить висновок, що теорія комунізму не є прямим продовженням матеріалістичного розуміння суспільства, а, навпаки, містить у собі обіцянку, що основні положення історичного матеріалізму перестануть бути обов'язковими у майбутньому [7, с. 90 92].

Таким чином, згілно з концепціею засновників марксизму, комуністична суспільно-економічна формація ліквідує будь-які прояви відчуження. Останне ознаменуе собою настання якісно нової ери, що прийде на зміну класовим суспільствам. Роль соціалістичної революції полягає саме в тому, щоб здійснити «стрибок в царство свободи». Дана ідея нагадуе есхатологічні уявлення про раптовий перехід від несправжнього існування до справжнього. Тому, на думку А.С. Панаріна, «в основі марксистської релігії лежить секуляризований неусвідомлений хіліазм» (цит. за [3, с. 117]) як віра в тисячолітне досконале царство на 
землі.

XIX століття в історії філософської думки позначене появою (поряд 3 грандіозними класичними раціоналістичними системами та «науковими проектами») ірраціоналістичних вчень. Дана обставина вплинула й на розвиток філософсько-історичної думки. Виникли т. зв. ірраціоналістичні трактовки ідеї кінця історії, до яких можна віднести й філософські положення такого оригінального мислителя, як Ф. Ніцше. Його небезпідставно вважають одним із пророків трагедій XX століття, оскільки ідея надлюдини об'єктивно виявилась теоретичним попередником реальних тоталітарних вождів. Однак, як і у випадку 3 Марксом, скоріш за все, задум був абсолютно іншим, ніж це продемонструвала історична практика.

Ніцше говорить про людину як про «канат, натягнутий між твариною і надлюдиною, канат над проваллям», як про «міст, а не мету» $[23$, c. 9-10]. Натомість надлюдина - це істота, яка, будучи очищеною від ресентименту та духу помсти, здійснить радикальний розрив з попередньою цивілізацією та її інститутами: від держави і права до любові та моралі. На думку Ніцше, на зміну цивілізації, побудованій на протиприродних цінностях, проголошених Сократом і Христом, має прийти новий тип культури, котрий призведе до натуралізації людини та іï возз'єднання 3 природою. Він пишаеться тим, що, ніби динаміт, підірвав тисячолітні заборони, проголосив прорив «по ту сторону добра і зла» - прорив до надлюдини, тим самим «розрубивши історію навпіл». Тому можна цілком погодитись з В.Н. Мироновим, який зауважує, що «ніцшеанський проект надлюдства $\boldsymbol{\epsilon}$ змістовно близьким до марксизму: ніцшевське поняття ресентименту відповідає марксистській категорії відчуження». Вони «позначають різні модуси втрати людиною власної сутності» відповідно в культурній та економічній сферах $[22$, c. 169]. Відтак і Маркс, і Ніцше пропонували власні проекти майбутнього як проекти визволення людини, хоча й виходили з різних світоглядних позицій. Цікаво порівняти ще й позиції Ніцше та Достоєвського. Так, останній також говорить про людину як про «слабосильну істоту», однак, на відміну від Ніцше, винуватить не християнство, а недосконалу природу людини. Більше того, Достоєвський зауважує, що християнське віровчення дає «вершині Божого творіння» надзвичайну свободу, але для більшості людей вона виявляеться нестерпним тягарем. I тому Великий інквізитор з «Братів Карамазових» пророкуе настання «царства спокою і щастя», адже «все, чого шукає людина на землі: перед ким схилитися, кому вручити совість та яким чином поєднатися нарешті усім в беззаперечний загальний і одностайний му- 
рашник» $[14$, c. 282$]$.

Питання про кінець історії ставилося і в російській релігійній філософії початку XX століття. Зокрема, тема осмислення сутності і спрямованості історичного процесу була надзвичайно близька таким мислителям, як М.І. Бердяев та В.С. Соловйов. У кожного 3 них можна віднайти тези, які $є$ не просто співзвучними ідеї історичного фіналізму, а й цілісну концепцію власного варіанту кінця історії (причому вони обидва вживали це поняття у своїх творах).

Бердяєв свідомо протиставляє власне бачення сутності історичного процесу домінуючому на той час вченню - «релігії прогресу». Останнє, на його думку, представляе собою двічі спотворену християнську ідею спасіння: спочатку у вигляді хіліастичного вчення, а потім - «позитивної ідеї прогресу». Тому сподівання численних авторів «утопій земного раю» (Конт, Гегель, Спенсер, Маркс) на «іманентне вирішення трагедії всесвітньої історії і настання досконалого стану» Бердяєв називае хибними, оскільки «науково-позитивно можна обгрунтувати тільки теорію еволюції, а вчення про прогрес може бути тільки предметом віри» [6, с. 145-149]. Більше того, мова йде не просто про неможливість наукового доведення обов'язкового розв'язання історичної драми в межах самої історії. Важливішим для Бердяева $є$ т. зв. моральний аргумент. Адже ідея прогресу перетворюе кожне покоління людей на засіб досягнення прийдешнього суспільного блаженства, що, звичайно, суперечить релігійній ідеї воскресіння усіх померлих і повстання їх перед останнім Божим судом. Тому російський філософ називає майбутне «покоління щасливчиків» «вампірами по відношенню до усіх попередніх поколінь» $[6$, с. 148$]$.

На противагу філософсько-історичним вченням, що базуються на секуляризованій ідеї спасіння, Бердяєв висувае концепцію, відповідно до якої історія має «вищий сенс», а «Царство Боже-мета історії, кінець історії, вихід за межі історії» [5, с.714]. Отже, в його концепції, як і в Августина, історія - це «шлях до іншого світу», в якому буде переможений час і настане вічність.

3 аналогічної (релігійно-філософської) позиції висловлював свої ідеї і Соловйов. Однак у нього можна прослідкувати еволюцію уявлень про завершення історичного процесу. Якщо спочатку він виходив із прогресистських позицій, то наприкінці своєї творчої біографії перейшов на позиції соціального катастрофізму. Так, у «Читаннях про Боголюдство» історія розуміється ним як Боголюдський процес втілення Божества і обожнення людини, тобто послідовного поєднання «віри в Бога і віри в людину» [28, с. 33-34]. 3 оптимістичних позицій 
він розробляє теократичну утопію, засновану на ідеї всеєдності. Однак у більш пізній роботі «Три розмови про війну, прогрес та кінець всесвітньої історії. .. » він виходить з песимістичної позиції і проголошуе, що «розв' язка нашого історнчного процесу» полягае у «появі, прославленні та катастрофі антихриста» [27, с. 437].

Необхідно відмітити, що тема зла в історії (взагалі та особливо в її кінці) та теодицеї була дуже популярною в російському інтелектуальному середовищі початку XX століття. Той же Бердяев говорив, що «антихрист $є$ проблемою метафізики історії» і що «зло прийдешнього століття буде страшнішим, ніж зло минулого» [6, с. 159]. Проте, незважаючи на «невдачу історії», вона обов'язково має завершитись виходом у пост-історію.

Філософсько-історичні ідеї В.С. Соловйова стали предметом детального вивчення французького дослідника російського походження, оригінального інтерпретатора вчення Гегеля та одного 3 натхненників постмодернізму - О.В. Кожева (Кожевникова). Зокрема, він зауважує, що Соловйов здійснив тривалий шлях від крайнього оптимізму до песимізму у відношенні історичної долі російського народу. Але, 3 його точки зору, мислителю не вдалося побудувати завершену метафізику, котра $б$ відповідала пізній позиції самого Соловйова, відповідно до якої людина визнаеться тільки матеріальним носіем, а не втіленням істини [13, с. 157]. Тому подальша діяльність Кожева - 3 приводу інтерпретації «Феноменології духу» Гегеля - була, ймовірно, покликана виконати поставлене російським філософом завдання. Більше того, B.I.Россман стверджуе, що «кінець історії, за Кожевим, - те ж, що і в Соловйова, тільки без другого пришестя» [25, с. 102].

Згідно 3 позицією одного 3 кращих у післявоєнній Европі коментаторів Гегеля, історія тлумачиться як сцена, на якій розгортається боротьба між панською і рабською свідомістю, а результатом цієї боротьби є поява людини. Причому мова йде про конкретних людей i конкретну боротьбу, що зближуе позицію Кожева з матеріалістичним розумінням історії. Діалектичне розгортання історії, по суті, е «діалектикою» Пана і Раба і поділяється на три етапи. Перший етап, який відповідає періоду античності, характеризується виокремленням людини $з$ природного середовища і домінуванням Пана. Останній демонструе бажання ризикувати життям заради визнання і перемагає Раба. Раб, у свою чергу, підкорюється шляхом часткового «діалектичного зняття». Оскільки Раб у свідомості Пана з часом перетворюеться на одну із «речей», то його задоволеність від перемоги стає ілюзією (Пан хоче визнання від людини). Відтак починається новий виток історії, 
що хронологічно відповідае періоду середньовіччя. Той ідеал людини, який зародився в Панові, може «втілитися в життя, розкритися тільки в Рабстві і через Рабство». Так, якщо Пан здійснив свою свободу шляхом подолання в Боротьбі інстинкту самозбереження, то Раб робить те ж саме через Працю (він працюе на іншого, долаючи свої інстинкти, покликані задовольняти власні потреби).

Таким чином, Раб визнае свободу Пана, його людську гідність. Але свобода самого Раба є абстрактною, оскільки немає зворотного визнання. Тому, слідуючи діалектичній схемі, Кожев наголошуе на тому, що для того, аби «досягти остаточного Задоволення, яке дається взаємним Визнанням», Рабу необхідно нав'язати свою волю Пану. А для цього йому слід вступити з Паном в боротьбу, відповідно - перестати бути Рабом.

Пояснюючи механізм відмови Раба від своеї рабської сутності, Кожев частково бере на озброєння аргументацію Ф. Ніцше. Так, зокрема, він стверджує, що це можна здійснити тільки шляхом «позбавлення від рабської сторони Християнства», адже Бог-це теж Пан, хоча й потусторонній. Відтак, на думку Кожева, необхідно «спустити Небо на Землю», а «людина мае сама стати Ісусом Христом» [18, с. 243-244]. I тільки тоді Раб зможе боротися за визнання в земному світі, результатом чого стане діалектичне зняття (або ж діалектичний синтез) Пана і Раба. А це, у свою чергу, ознаменуе собою завершення історії («історія зупиняеться в ту мить, коли зникае відмінність, протистояння Пана і Раба, коли Пан перестає бути Паном, оскільки немає більше Рабів, а Раб перестає бути Рабом, оскільки немае більше Пана, але він не стае при цьому Паном, оскільки Рабів більше немає» [18, с. 218]).

Кожев вважав себе «двійником» Гегеля і наголошував на тому, що він претендуе виключно на коментування його «Феноменології духу». Однак на його філософську позицію, без перебільшення, вплинули i марксизм, і феноменологія Е. Гуссерля, й екзистенційна аналітика буття М.Хайдеггера та інші післягегелівські вчення. Тому у Кожева яскраво виражена саме антропологічна інтерпретація Гегеля, на чому, звичайно, у самого німецького класика акцент не робився. Отже, якщо у Гегеля історія завершувалася самопізнанням Духу та саморозгортанням його свободи, то у його французького послідовника смертю людини, оскільки відсутність необхідності ризикувати життям (як це робив Пан) та працювати до виснаження (як це робив Раб) повертають людину до тваринного стану. В кінці історії «живі істоти, що мають тілесну форму», насправді не мають «Духа». Разом 3 людиною вмирають диференційована станова держава, репрезентативне 
мистецтво, філософія та лицарські цінності $[25$, с. 96$]$.

Ідеї Гегеля та Кожева, у свою чергу, стали важливим теоретичним джерелом концепції відомого популяризатора тези про кінець істоpiї- американського мислителя японського походження Ф. Фукуями. Піднімаючи питання про можливість існування «Універсальної Історії людства», останній підкреслюе, що тим самим він «відновлюе дискусію, котра виникла на початку XIX століття, але в наш час більш чи менш затихла через чисельність подій, що відбулися 3 тих пір 3 людством» $[29$, с. 11]. Йому, дійсно, вдалося актуалізувати питання кінця історії, оскільки стаття 3 аналогічною назвою була перекладена багатьма мовами, а основні її ідеї широко обговорюються й донині. Свої застереження та коментарі з приводу проголошених Фукуямою положень в різні роки висловлювали П. Андерсен, А. Блюм, І. Крістл, Д.П. Моніхан, М. Мейер, С. Хантінгтон, Г. Хіммелфаб, Кл. Фрідріх та інші дослідники. В рамках вітчизняного філософського дискурсу, на наш погляд, ідеї американського мислителя були, здебільшого, проінтерпретовані не зовсім вірно. Концепцію Фукуями слід розглядати в руслі філософії ідей, а не з точки зору діалектичного та історичного матеріалізму. Адже він говорить про кінець історії саме як про «відсутність життєздатних альтернатив лібералізму», причому таких, які $б$ складали «загальний для всього людства ідеологічний фонд» $[30$, c. 139], тобто таких, які б мали оптимальні механізми для поширення свободи. Отже, «кінець історії, за Фукуямою, це не просто кінець «холодної війни» чи певного періоду суспільного розвитку, а кінець історії як такої (Історії як еволюційного процесу самореалізації свободи в усьому світі, «свідомого зусилля абстракції, в якій події важливі відокремлюються від неважливих», а не історії як сфери повсякденних подій, «каталогу всього, що відбувалося в минулому» [29, с. 222]). Тобто, на його думку, це остання точка в ідеологічній еволюції людства й універсалізація західної ліберальної демократії. Причому перемога лібералізму спочатку має місце в «сфері ідей чи свідомості», а вже потім - «в реальному чи матеріальному світі». Крім того, як зауважуе Р. Кемпбел, під кінцем в концепції Фукуями необхідно мати на увазі скоріше телос, «здійснення», ніж «фініш» або «завершення», «закінчення» (див.: [35]).

Однак, кінець історії як остаточний тріумф свободи - це тільки один із аспектів розуміння Фукуямою даної проблеми. Тут він виступає з позиції неогегельянства. Але в кінці своєї відомої статті він висловлюе ностальгію «за часом, коли була історія». Адже в їі кінці на зміну «боротьбі за визнання, готовності ризикувати життям заради 
виключно абстрактної мети, ідеологічній боротьбі, що вимагае відваги, уяви та ідеалізму» приходять «економічний розрахунок, безкінечні технічні проблеми, турбота про екологію та задоволення витончених запитів споживача» [30, с. 148]. В даному аспекті позиція дослідника близька до ідей $\Phi$. Ніцше (про «останню людину» як про «найбільш зневажливу людину») та Ж. Бодріяра (про споживацьке суспільство). Отже, ставлення Фукуями до кінця Історії є глибоко амбівалентним, оскільки дана ідея виступае у нього і як тріумф свободи, і одночасно як «сумний час», оскільки «остання людина перестає бути людиною».

В подальшій творчій діяльності Фукуяма, будучи високопоставленим чиновником в США, робить акцент саме на першому аспекті розуміння кінця історії (перемога Заходу як типу культури). Зокрема, в статті за 2002 рік він наголошуе на тому, що «існують усі підстави для того, аби вважати, що західні цінності та інститути значною мірою прийнятні для багатьох, якщо не для більшості, незахідних народів». Фукуяма не заперечуе, що сучасна демократія - надбання саме західної цивілізації, побудованої на християнських цінностях. Однак, він порівнюе її роль $з$ роллю наукового методу (ще одного культурного здобутку Заходу), зауважуючи, що і те й інше «володіє універсальною здатністю щодо застосування» [31, с.480]. Отже, на поставлене ним питання «Чи почалася історія знову?» американський популяризатор ідеї кінця історії відповідає заперечно.

Розглянувши проблему постановки питання кінця історії у світовій філософії, маемо зауважити, що, напевне, усі соціально-філософські концепції, автори яких намагалися цілісно підійти до осмислення історичного процесу, так чи інакше стосуються розробки досліджуваного питання. Починаючи від Платона і, особливо, Августина ідея історичного фіналізму у різноманітних варіаціях стала важливим компонентом подальших спроб визначити суть та спрямованість Історії. Дану ідею можна відшукати в утопістів пізнього Відродження, у просвітників, Гердера, Віко, Канта, Гегеля, Конта, Спенсера, Маркса, Ніцше, Достоєвського, Бердяєва, Соловйова, Кожева, Фукуями та інших мислителів, які виходили з різних світоглядних позицій, але змальовували власні проекти найкрашого, з їх точки зору, суспільного устрою, реалізація котрого означала б вирішення основних проблем людства.

\section{1 Бібліографія}

[1] Аврелий Августин. О Граде Божием. - М.: АСТ, 2000. 
[2] Арон P. Етапи розвитку соціологічної думки / Пер. 3 фр. Г. Філіпчука. - K.: Юніверс, 2004.

[3] Барабаи O.B. Есхатологія та утопія в розумінні історії. Дисертація на здобуття ступеня кандидата філософських наук. - Харків, 2000 .

[4] Бауэрмаи P. Нищета «марксологии». Критика фальсификаций учения Маркса и Энгельса / Пер. с нем. - М.: Политиздат, 1976.

[5] Бердяев H. Судьба Росси: Сочинения. - М.: Изд-во ЭКСМОПресс; Харьков: Изд-во Фолио, 1998.

[6] Бердяев Н.А. Смысл истории. - М.: Мысль, 1990.

[7] Валіщький A. Марксизм і стрибок у царство свободи: Історія комуністичної утопії. - К.: Всесвіт, 1999.

[8] Вико Дюк. Основания Новой науки / Пер. с итал.-M.-K.: REFLbook- ИCA, 1994.

[9] Гвардини P. Конец философии нового времени // Феномен человека: Антология. - М.: Высшая школа, 1993. - С.240-296.

[10] Гегель Г.В.Ф. Лекции по философии истории.-СПб.: Наука, 2000.

[11] Гердер И.Г. Идеи к философии истории человечества. - М.: Наука, 1977.

[12] Гоббс T. Человеческая природа // Гоббс Т. Сочинения в 2 т. Т. 1. М.: Мысль, 1989. - С. 507-573.

[13] Гройс Б. Философ после конца истории // Ускользающий контекст. Русская философия в постсоветских условиях. Материалы конференции (Бремен, 25-27 июня 1998г.). - M.: Ad Marginem, 2002. - C. 147-160.

[14] Достоевский Ф.М. Братья Карамазовы. Роман в четырёх частях с эпилогом. - Петрозаводск: Карельское книжное издательство, 1970.

[15] Запорожець T.B. Утопічна свідомість як атрибутивна характеристика перехідного періоду. Дисертація на здобуття ступеня кандидата філософських наук. - Луцьк, 1999. 
[16] Кант И. Идея всеобщей истории во всемирно-гражданском плане // Кант И. Сочинения в 6 т. - М.: Мысль, 1966. - Т. 6. - С. 5-23.

[17] Каримский А.М. Философия истории Гегеля.-М.: Изд-во МГУ, 1988.

[18] Кожев А. Введение в чтение Гегеля. Лекции по Феноменологии духа, читавшиеся с 1933 по 1939г. в Высшей практической школе. Пер. с фр. А.Г. Погоняйло. - СПб.: Наука, 2003.

[19] Ломоносов Ю.Л. «Конец истории» как социофилософская проблема. Диссертация на соискание учёной степени кандидата философских наук. - М., 2002.

[20] Лосев А.Ф. Античная философия истории. - М.: Наука, 1977.

[21] Маркс K. Критика Готской программы // Маркс К., Энгельс Ф. Соч. - М.: Изд-во полит. лит-ры, 1974. - Т. 19. - С. 9-32.

[22] Миронов В.Н. Философия истории Фридриха Ницше // Вопросы философии. - 2005. - 추 11. - С. 163-175.

[23] Huцие Ф. Так говорил Заратустра; К генеалогии морали; Рождение трагедии, или Эллинство и пессимизм: Сборник / Пер. с нем. - Мн.: Попурри, 2001.

[24] Перов Ю.В., Сергеев К.А. «Философия истории» Гегеля: от субстанции к историчности // Гегель Г.В.Ф. Лекции по философии истории. - СПб.: Наука, 2000. - С. $3-53$.

[25] Россман В.И. Александр Кожевников: между евразийством, Латинской империей и «концом истории» // Актуальні проблеми духовності. - Зб. наукових праць. Вип. 4(1).-Кривий Ріг: IBI, 2002. - C. $92-104$.

[26] Сергейчик E.M. Философия истории.-СПб.: Лань, Санкт-Петерб. УН-т МВД России, 2002.

[27] Соловъёв В.С. Три разговора о войне, прогрессе и конце всемирной истории // Соловьёв В.С. Сочинения. - М.: Раритет, 1994.C. $315-438$.

[28] Соловъёв B.C. Чтения о Богочеловечестве // Соловьёв В.С. Сочинения. - М.: Раритет, 1994. - С. 13-168. 
[29] Фукуяма Ф. Конец истории и последний человек / Пер. с англ.M.: ACT: Ермак, 2005.

[30] Фукуяма Ф. Конец истории? // Вопросы философии. - 1990.№3. - C. $134-148$.

[31] Фукуяям Ф. Чи почалася історія знову? // Дух і літера.-К., 2004. - № 13-14. - C. 478-487.

[32] Чанымев A.A. «Град земной» в эсхатологической перспективе: переосмысление опыта античной истории и гражданской культуры в историософии Августина // Вопросы философии. - 1999. № 1. - C. 124-135.

[33] Энеельс Ф. Людвиг Фейербах и конец классической немецкой философии // Маркс К., Энгельс Ф. Избранные произведения в 3-х т. - Т. 3. - М.: Изд-во полит. лит-ры, 1966. - С. 371-415.

[34] Ящук T.I. Філософія історії: Курс лекцій. - К.: Либідь, 2004.

[35] Kimball R. Francis Fukuyama and the end of history // newcriterion.com:81/archive/10/feb92/fukuyama.htm 